\title{
MANIFESTATION OF THE TEACHER'S REFLECTIVE PRACTICE AS EXPERIENTIAL LEARNING AND INVESTIGATION OF ONE'S ACTIONS IN PROFESSIONAL ACTIVITIES
}

\author{
Remigijus Bubnys \\ Šiauliai University, Lithuania \\ Aida Kairienè \\ Šiauliai University, Lithuania
}

\begin{abstract}
The article deals with the teacher's reflective practice as manifestation of learning from experience and investigation of one's actions in professional activities, presenting the results of the quantitative empirical study. The conducted exploratory factor analysis, applying rotation of factor axes by Varimax method enabled to identify significant factors of the teacher's reflective practice. Four statistically significant factors were distinguished: investigation of professional and personal activities as a guarantee of accumulation and improvement of professional experience; analysis and refection on personal experience as a factor motivating learning; dissemination of acquired experience in the interaction with school community members as a possibility to learn; learning from the experience as a precondition for success of the learning organization.

Research results revealed that teachers understand the importance of learning from experience; however, they are not inclined to conduct a deeper analysis of their practice.
\end{abstract}

Keywords: teacher, learning from experience, professional activities, reflective practice.

\section{Introduction}

Currently, teachers have to meet increasingly higher requirements both for their professional activity and personality. Teachers become not only knowledge carriers but also professionals who are constantly improving in their field and actively acting in the learning organization. Transformations of the society and expanding intercultural relations also determine changes in the education system, reflected in strategic planning documents. The fundamental vision of the strategy "Education 2030" is to ensure inclusive and equitable quality education and promote lifelong learning possibilities for all. This is a humanistic vision of education, based on human rights and dignity, social justice, inclusion, protection, cultural, linguistic and ethnic diversity, and shared responsibility and accountability. Education is a public good, a fundamental human right, guaranteeing the realisation of other rights and focusing efforts on access, equity and inclusion, quality and learning outcomes within a lifelong learning approach 
(Education 2030: Towards Inclusive and Equitable Quality Education and Lifelong Learning for All, 2015). Implementation of this vision requires skilled, motivated, effectively working and critically thinking professional teachers, who are able to respond to the changing needs; they need appropriate support and good possibilities for continuous professional development. Modern teachers accept new challenges, expand and renew their skills and perform more effectively than ever before (The Teaching Profession in Europe Practices, Perceptions and Policies Eurydice Report, 2015).

Many researchers (Smith, 2003; Ghaye, 2010; Burbank et al., 2012; Marzano et al., 2012; Zwozdiak-Myers, 2012; Sellars et al., 2014) analyse the teacher's reflective practice in various aspects. Prospects of teachers' critical reflective thinking, preparing them for work with different groups of pupils, are investigated by Burbank et al. (2012), who disclose peculiarities of approach formation in classroom conditions. Ghaye (2010) analyses types of knowledge necessary for professional teachers, professional expertise, emphasise the importance of redesigning practice in order to better understood and disclose peculiarities of reflective practice. The self-assessment process created by Marzano et al. (2012) enables to identify the goals of the teacher's professional growth and helps to quickly learn reflective behaviour strategies to achieve these goals. Zwozdiak-Myers (2012) in her study highlights that teachers who raise questions about the teaching and learning practices, considering their own situation, are interested in lifelong learning, look for new ideas and seek improvement of their performance. Sellars (2014) emphasises that reflective practice enables teachers to change their thinking and encourages them to justify their beliefs.

The research problem: There are a number of studies on the teacher's reflective practice but it is purposeful to analyze reflective practice by separate attributes, as the latter phenomenon is multidimensional and can be differently characterized by different authors. The problem question is formulated: What are the manifestation of the teacher's reflective practice as learning from experience and investigation of personal activities in professional activities?

The research object: manifestation of the teacher's reflective practice as learning from experience and investigation of one's actions in professional activities.

The research aim: to disclose the manifestation of the teacher's reflective practice as a learning from experience and investigation of one's actions in professional activities. 


\section{Attributes of the Teacher's Reflective Practice in Professional Activities}

Based on Rogers' evolutionary concept analysis (1989), it was found that the teacher's reflective practice was a complex concept, encompassing the dimension of teaching and learning, thinking and investigation, seeking professional and personal development (Bubnys \& Kairiené, 2016). The following attributes were distinguished: learning from experience, deep critical thinking, investigation of one's actions, seeking professional and personal improvement. This article deals with the results of manifestation of the teacher's learning from experience and investigation of one's actions in professional activities. Learning from experience helps to plan one's activities, relate theoretical knowledge to practice, facilitates orientation in various activity situations, promotes teachers' cooperation and creativity. It starts with the analysis of one's actions in professional situations; therefore, investigation of one's performed actions enables application of theoretical knowledge in practice, the increase of effectiveness of teaching and learning and effective evaluation of one's feelings and experience.

Learning from experience. Reflective teachers learn from experience and develop a critical approach to teaching and learning (Harrison, 2010). Experiential learners investigate their experience, reflect, think and act in a recurring cycle that is responsive to the learning situation (Kolb \& Kolb, 2005). Teachers need a pause to give questions arising from their performance result (Harrison, 2010). Reflecting on experience, teachers analyze different questions: What were the pupils learning? What have they learned? and Why? for a deeper analysis (Moon, 2004). In their professional activities, teachers both analyse their experience and learn from others (Rushton \& Suter, 2012), create new knowledge and use it for improvement of their actions (Loughran, 2002). We can state that learning from experience is a critical view (reflection) towards teaching and learning, promoting to periodically give questions (think) about one's own and others' performance results so that teachers can acquire new knowing of how to effectively act in professional situations.

Investigation of performed actions enables teachers to perceive similarities and shortcomings of their professional activities and promotes professional wisdom, fosters deeper understanding (Ghaye, 2010). Their ability to consider teaching and learning and to reflect on one's as the teacher's actions is an essential condition for successful teaching and learning. The disposition to investigate one's actions enables teachers to shape their beliefs, values, knowledge and theories, and look deeper into oneself (Zwozdiak-Myers, 2012). Investigation of professional activities leads to a more effective learning process, changes the teacher's approach, ensures a realistic assessment of the teaching and learning situation (Cartwright \& McGregor, 2011). It is only the 
analysis of one's actions that enables to understand what is being done properly, what mistakes are made, this way cognising and actually evaluating the teaching and learning situation, creating a moral and informational base for effective learning processes.

\section{Research Methodology}

The research sample. The research sample was formed applying convenience sampling (Cohen et al., 2007). The research sample is purposive too; it includes and represents the entire population of the research. In total, 352 full-time teachers worked in 8 gymnasiums of Šiauliai city (Lithuania) during the research. The questionnaires were completed by 256 teachers, of whom: 32 (12,5 percent) were male, 216 ( 84,4 percent) were female and 8 (3,1 percent) didn't indicate their gender. The reversibility quota of questionnaires is 72,7 percent.

The research method. Data collection: data were collected applying a written survey (using semi-closed questions) method, which allows teachers to assess the attributes of the teacher's reflective practice. Data analysis: research data were analyzed using SPSS 17.0 statistical software package: the exploratory factor analysis was performed applying rotation of factors axes by Varimax method; suitability for the factor analysis was assessed by the KMO measure and Bartlett's test of sphericity; internal consistency and reliability of scales was tested by Cronbach's alpha coefficient.

The research instrument. Teachers evaluated questionnaire statements (describing reflective practice as investigation of one's actions and as learning from experience in the teacher's professional activities), selecting variants of possible answers according to 5 - level scale: 1 - strongly disagree, 2 - disagree, 3 - doubt, 4 - agree 5 - strongly agree. The results are analyzed according to the means of statements and adding up the values of "agree" and "strongly agree", and "strongly disagree" and "disagree" respectively.

\section{Research Results and their Analysis}

The factor analysis of statements about teachers' reflective practice resulted in four statistically significant and interpretable factors (see Table 1).

Fluctuation limits of correlation coefficient values $(0,53 \leq \mathrm{r} \leq 0,75)$ indicate that quite high correlations of empirical statement estimates with distinguished factors were obtained. The value of the KMO coefficient of the scale 0,92 indicates that the matrix is well suited for the factor analysis. The scale characterized by 61,3 percent dispersion (from 21,7 percent to 10,8 percent) indicates that all factors account for at least 10 percent of the dispersion and are 
interpretable. The internal consistency coefficient of factors Cronbach's alpha $(\alpha)$ ranging from 0,80 to 0,91 indicates that the scale is homogeneous. Variables of factors satisfy the condition $\mathrm{L} \geq 0,5$ and from the methodological standpoint can be regarded as indivisible.

Table 1 Data of Factor Analysis of Teachers' Reflective Practice

\begin{tabular}{|c|c|c|c|c|c|c|}
\hline \multirow{2}{*}{ Name of the factor } & \multirow{2}{*}{ KMO } & \multirow{2}{*}{$\begin{array}{c}\text { No. of } \\
\text { statements }\end{array}$} & \multicolumn{2}{|c|}{$\begin{array}{l}\text { Suitability of } \\
\text { scale }\end{array}$} & \multicolumn{2}{|c|}{ Reliability of scale } \\
\hline & & & \begin{tabular}{|c|}
$\mathbf{L}$ \\
interval
\end{tabular} & percent & \begin{tabular}{|c|} 
r/itt \\
interval
\end{tabular} & $\begin{array}{c}\text { Cronbach's } \\
\alpha\end{array}$ \\
\hline $\begin{array}{l}\text { Investigation of professional and } \\
\text { personal activities as a guarantee } \\
\text { of accumulating and improving } \\
\text { one's professional experience. }\end{array}$ & \multirow{4}{*}{0,92} & 9 & $0,56-0,78$ & 21,7 & $0,56-0,75$ & 0,91 \\
\hline $\begin{array}{l}\text { Analysis of personal experience } \\
\text { and reflection as a factor } \\
\text { promoting learning. }\end{array}$ & & 7 & $0,55-0,79$ & 16,2 & $0,61-0,67$ & 0,86 \\
\hline $\begin{array}{l}\text { Spread of acquired experience in } \\
\text { the interaction with school } \\
\text { community members as a } \\
\text { possibility to learn. }\end{array}$ & & 4 & $0,64-0,81$ & 12,6 & $0,53-0,73$ & 0,82 \\
\hline $\begin{array}{l}\text { Learning from the experience as } \\
\text { a precondition for the success of } \\
\text { the learning organization. }\end{array}$ & & 3 & $0,62-0,84$ & 10,8 & $0,61-0,68$ & 0,80 \\
\hline
\end{tabular}

Investigation of professional and personal activities. The first factor consists of 9 statements (see Table 2), the contents of which disclose the need for teachers' reflective practice in order to acquire new knowledge, better understand and apply it in practice in order to improve performance effectiveness. Means of statements (M) fluctuate between 4,19 and 4,40.

The majority of teachers (95,7 percent) acknowledge the importance of investigating their professional activities; they understand that such investigation enables to apply theoretical knowledge in practice (94,6 percent), provides possibilities to improve their professional activities (94,2 percent), identifies advantages and shortcomings of professional activities (91 percent), promotes professional wisdom (90,6 percent) and enhances effectiveness of teaching $(90,6$ percent). Research results demonstrate that the evaluation of statements is positive $(\mathrm{M}>3,5)$, the highest values are given to understanding and new knowledge acquisition $(\mathrm{M}=4,40)$, the lowest, to the impact of investigation of actions on effective evaluation of one's experience $(M=4,19)$. Teachers, although being aware of the importance of investigation, still lack knowledge and skills for assessment of reflective practice. 
Table 2 Investigation of Professional and Personal Activities as a Guarantee of Accumulation and Improvement of Professional Experience

\begin{tabular}{|l|c|c|}
\hline \multicolumn{1}{|c|}{ Statements } & $\mathbf{M}^{*}$ & $\mathbf{S D}^{* *}$ \\
\hline $\begin{array}{l}\text { I } \text { investigate my activities so that I can better understand and acquire new } \\
\text { knowledge. }\end{array}$ & 4,40 & 0,55 \\
\hline $\begin{array}{l}\text { The analysis of personal actions is the possibility to apply theoretical } \\
\text { knowledge in professional practice. }\end{array}$ & 4,36 & 0,63 \\
\hline $\begin{array}{l}\text { The analysis of performed actions provides possibilities to improve } \\
\text { professional activities according to disclosed significant results. }\end{array}$ & 4,36 & 0,63 \\
\hline $\begin{array}{l}\text { Investigation of personal actions enables to look at existing knowledge and } \\
\text { experience anew. }\end{array}$ & 4,33 & 0,59 \\
\hline $\begin{array}{l}\text { Investigation of personal activities enables to increase effectiveness of } \\
\text { teaching and learning. }\end{array}$ & 4,31 & 0,63 \\
\hline Investigation of one's actions promotes professional wisdom. & 4,30 & 0,64 \\
\hline $\begin{array}{l}\text { Investigation of professional activities enables identification of advantages } \\
\text { and shortcomings of professional activities. }\end{array}$ & 4,25 & 0,63 \\
\hline $\begin{array}{l}\text { Investigation of personal activities and analysis of its results are a significant } \\
\text { and important activity in the teacher's professional practice. }\end{array}$ & 4,25 & 0,66 \\
\hline $\begin{array}{l}\text { Investigation of one's actions creates conditions to effectively self-assess } \\
\text { one's feelings and experiences. }\end{array}$ & 4,19 & 0,65 \\
\hline
\end{tabular}

* $\mathrm{M}$ - the mean shows the average value of all responses to the statement, which enables to judge the overall assessment of the feature (1-2,5 is a negative level, 2,5-3,5 is a neutral level, 3.55 is a positive level).

** SD - standard deviation shows the average dispersion of answers to the statement around the mean, showing the range where values of responses of the target group may moderately vary.

The analysis of personal experience and reflection as a factor promoting learning. The second factor consists of 7 statements that disclose making important decisions by reflecting on performed actions and future prospects, reflection on actions in the past, and the analysis of experience encountering difficulties in different activity situations at school (see Table 3). Means of statements (M) range from 4,06 to 4,32.

The majority of teachers (94,6 percent) reflect on their actions and possibilities making important decisions, they reflect on their actions in the past in order to learn from them in the future (93,0 percent), analyse thoughts based on lived experience (94,2 percent), analyze their experience in different activity situations (89,1 percent) and encountering difficulties (84,4 percent). Assessment of statements is positive $(M>3,5)$. Teachers find it more difficult to analyze their experience in different activity situations $(M=4,06)$. 
Proceedings of the International Scientific Conference. Volume II, May $27^{\text {th }}-28^{\text {th }}$, 2016. 40-50

Table 3 Analysis and Reflection on Personal Experience as a Factor Promoting Learning

\begin{tabular}{|l|c|c|}
\hline \multicolumn{1}{|c|}{ Statements } & M & SD \\
\hline $\begin{array}{l}\text { Making important decisions, I reflect on actions in the past, possibilities and } \\
\text { future prospects. }\end{array}$ & 4,32 & 0,58 \\
\hline I reflect on my actions in the past so that I can learn from them in the future. & 4,27 & 0,65 \\
\hline $\begin{array}{l}\text { Planning activities, I analyze my thoughts based on previously lived } \\
\text { experience. }\end{array}$ & 4,26 & 0,56 \\
\hline $\begin{array}{l}\text { Having accomplished obligatory activities at school, I reflect and analyze } \\
\text { my experience (thoughts and actions). }\end{array}$ & 4,25 & 0,60 \\
\hline $\begin{array}{l}\text { The analysis of personal experience enables to learn and look at the } \\
\text { situation anew. }\end{array}$ & 4,23 & 0,59 \\
\hline $\begin{array}{l}\text { Encountering difficulties in professional activities, I try to learn from } \\
\text { previously lived experience. }\end{array}$ & 4,16 & 0,64 \\
\hline $\begin{array}{l}\text { I always try to analyze my experience in different activity situations at } \\
\text { school. }\end{array}$ & 4,06 & 0,67 \\
\hline
\end{tabular}

Spread of acquired experience in the interaction with school community members as a possibility to learn. The third factor consists of 4 statements, its contents include trends of sharing acquired experience with others, disclose promotion of school administration to share lived experiences, created conditions and possibilities to share lived experiences with other members of the community. Means of statements (M) range between 4,04 and 4,37 (see Table 4).

Table 4 Spread of Acquired Experience in the Interaction with School Community Members as a Possibility to Learn

\begin{tabular}{|l|c|c|}
\hline \multicolumn{1}{|c|}{ Statements } & M & SD \\
\hline $\begin{array}{l}\text { School administration promotes processes of learning from each other, } \\
\text { sharing lived experiences. }\end{array}$ & 4,37 & 0,65 \\
\hline $\begin{array}{l}\text { At school, I have possibilities to share my personal professional experience } \\
\text { with other teachers. }\end{array}$ & 4,25 & 0,65 \\
\hline $\begin{array}{l}\text { The school offers conditions promoting exchanges of experiences and } \\
\text { learning from each other. }\end{array}$ & $0,20,62$ \\
\hline $\begin{array}{l}\text { I share the results of teaching and learning experience with school } \\
\text { community members. }\end{array}$ & 4,04 & 0,69 \\
\hline
\end{tabular}

The majority of teachers (93 percent) agree that school administration encourages learning from each other's processes and maintain that the school creates conditions and possibilities to share lived experiences and learn from each other (91 percent). Teaching and learning results are shared with school community by 84,4 percent of respondents but 10,9 percent doubt about it. Assessment of statements is positive $(M>3,5)$. Teachers share lived experience 
most when they are promoted by school administration $(\mathrm{M}=4,37)$, but they find it more difficult to share acquired experience with community members $(\mathrm{M}=4,04)$. This suggests that sharing acquired experience promotes interrelationships between school authorities and community, enables to learn from each other.

Learning from experience as a precondition for success of the learning organization. The fourth factor consists of 7 statements that disclose learning from each other and with others, learning from one's experience, creating success of the learning school (see Table 5). Means of statements (M) fluctuate from 3,90 to 4,15 .

Table 5 Learning from Experience as a Precondition for Success of the Learning Organization

\begin{tabular}{|l|c|c|}
\hline \multicolumn{1}{|c|}{ Statements } & M & SD \\
\hline $\begin{array}{l}\text { The priority of every successful school is learning from each other and with } \\
\text { others. }\end{array}$ & 4,15 & 0,69 \\
\hline $\begin{array}{l}\text { Creation of conditions for learning from experience is a precondition for } \\
\text { success of the learning school. }\end{array}$ & 4,14 & 0,62 \\
\hline $\begin{array}{l}\text { Learning from experience in the organization "turns what is invisible into } \\
\text { what is visible". }\end{array}$ & 3,90 & 0,74 \\
\hline
\end{tabular}

The majority of teachers (88,3 percent) maintain that learning from each other is a priority of the successful school and a precondition for success of the learning school ( 88,7 percent). 77,0 percent of teachers believe that learning from experience in the organization allows to broaden horizons although 17,5 percent of respondents doubt about that. According to the means of teachers, learning from each other and with others $(M=4,15)$ is prioritised but they find it slightly more difficult to see the hidden aspects of the organization $(M=3,90)$.

\section{Discussion}

The structure of teachers' reflective practice attributes presented in the article is conditional but includes essential characteristics that enable to identify relevant trends of learning from experience and investigation of one's actions in professional activities. Research results disclose that learning from experience is a guarantee of success of the learning school organization. Experiential learning takes place by means of reflection, reflecting on concrete experience, formulating specific findings and trying out new ideas in different situations (Kolb \& Kolb, 2005). All of it allows to see the hidden aspects of the organization and improve its performance (Tikkamaki \& Hilden, 2014). Seeking success of the organization, learning takes place from both one's own and others 
teachers' experience (Harrison, 2008). Favourable conditions enable to achieve effective results and learn from each other. The study reveals four areas characterising features of reflective practice: the importance of investigating professional and personal activities for accumulation and improvement of professional experience; the impact of personal experience analysis and reflection on promotion of learning; the importance of spread of acquired experience in the school community for creation of favourable learning environment; and relevance of learning from experience seeking success of the learning organization.

Investigation of professional and personal activities in the structure of features in teachers' reflective practice is a component of investigating one's actions, enabling efficient creation of new knowledge and its usage for teaching and learning. The personal experience analysis and reflection stimulate learning, disclosing the importance of learning from experience for teachers' personal and professional development (Ghaye, 2010; Zwozdiak-Myers, 2012). The observed trends of spread of acquired experiences highlight the necessity of interaction between school community members. In practice, consideration of learning from experience partly depends on the individual approach. Results disclose that teachers understand the importance of learning from experience. However, they are not inclined to perform a deeper analysis of their practices. This presupposes the precondition that due to fast-paced work and the abundance of functions assigned to teachers, teachers do not have enough time to pause, look back and write down the questions about their actions in the lesson, calmly reflect on them and decide how they could act further. Similar studies (Tabassum \& Malik, 2014; Marzano et al., 2014) demonstrate that in most cases teachers' reflection is superficial, their knowledge of reflective practice is limited; therefore, it is also purposeful to analyse manifestation of attributes of their reflective practice in the aspects of deep critical thinking, professional and personal development, etc., choosing different research methodologies.

\section{Conclusions}

The results disclosed that the teacher's learning from the experience creates preconditions for successful implementation of the idea of the learning school. Investigation of professional and personal activities enables effective knowledge creation about professional practice and its use for teaching and learning. Spread of knowledge acquired during reflective practice at school expands learning possibilities of its community members; therefore, it is purposeful to promote cooperation and sharing best practices. Teachers' learning requires creation of favourable environment, purposive breaks for reflection on professional 
Remigijus Bubnys, Aida Kairiene. Manifestation of the Teacher's Reflective Practice as Experiential Learning and Investigation of One's Actions in Professional Activities

experiences and discussions about them with colleagues in order to promote deep critical thinking.

\section{References}

Bubnys, R., \& Kairienè, A. (2016). The Concept and Content of the Teacher's Reflective Practice: from Impulsiveness of Activities towards Personal and Professional Development. Pedagogy, 121 (1). Manuscript submitted for publication. [Lithuanian language].

Burbank, M., Bates, A., \& Ramirez, L. (2012). Critically Reflective Thinking in Urban Teacher. Education: A Comparative Case Study of Two Participants' Experiences as Content Area Teachers. Fall, 2, 1-17.

Cartwright, L., \& McGregor, D. (2011). Developing Reflective Practice: a Guide for Beginning Teachers. Maidenhead: McGraw-Hill: Open University Press.

Cohen, L., Manion, L., \& Morrison, K. (2007). Research Methods in Education (Sixth edition). London and New York: Routledge, Taylor and Francis Group

Education 2030: Towards Inclusive and Equitable Quality Education and Lifelong Learning for All. (2015). Incheon Declaration. UNESCO.

Ghaye, T. (2010). Teaching and Learning Through Reflective Practice: A Practical Guide for Positive Action. London and New York: Routledge.

Harrison, J. (2010). Professional Learning and the Reflective Practitioner. In Dymoke, S., Harrison J. Reflective teaching and learning, Chapter1, 6-46, London: Sage.

Kolb, A. Y., \& Kolb, D. A. (2005). Learning Styles and Learning Spaces: Enhancing Experiential Learning in Higher Education. Academy Of Management Learning and Education, 4 (2), 193-212.

Loughran, J. J. (2002). Effective Reflective Practice in Search of Meaning in Learning about Teaching. Journal of teacher education, 53 (1), 33-43.

Marzano, R. J., Boogren, T., Heflebower, T., Kanold-McIntyre, J., \& Pickering, D. (2012). Becoming a Reflective Teacher. USA: Solution Tree Press.

Moon. J. (2004). A Handbook of Reflective and Experiential Learning: Theory and Practice. London and New York: Routledge.

Rodgers, B. (1989). Concept Analysis and the Development of Nursing Knowledge: the Evolutionary Cycle. Journal of advanced nursing, 14, 330-335.

Rushton, I., \& Suter, M. (2012). Reflective Practice for Teaching in Lifelong Learning. McGraw-Hill: Open university press.

Sellars, M. (2014). Reflective Practice for Teachers. London: Sage Publications.

Smith, T. J. (2003). Connecting Theory and Reflective Practice Through the Use of Personal Theories. 27th International Group for the Psychology of Mathematics Education Conference, 215-222.

Tabassum, F., \& Malik, S. K. (2014). Teachers' Attitude towards Reflective Practice in Public and Private Sector at Higher Secondary Level. New educational review, 36 (2), 278-288.

Tikkamaki, K., \& Hilden, S. (2014). Making Work and Learning more Visible by Reflective Practice. Research in post-compulsory education, 19 (3), 287-301.

The Teaching Profession in Europe Practices, Perceptions, and Policies. (2015). Eurydice Report. 
SOCIETY. INTEGRATION. EDUCATION

Proceedings of the International Scientific Conference. Volume II, May $27^{\text {th }}-28^{\text {th }}$, 2016. 40-50

Zwozdiak-Myers, P. (2012). The Teacher's Reflective Practice Handbook: Becoming an Extended Professional through Capturing Evidence-Informed Practice. London and New York: Routledge.

Williams, M., \& Burden, R. L. (2000). Psychology for Language Teachers. Cambridge: Cambridge University Press. 